$\star$ Rhizomes: Cultural Studies in Emerging Knowledge: Issue 34 (2018)

\title{
The Arab Body
}

\author{
Victor L. Shammas
}

Abstract: The Arab body has long been a focal point of literary, political, technological, and military interventions. The state of otherness attributed to the embodied nature of Arab identity has made it a key locus of social domination as well as, more positively, a springboard for fresh takes on social domination far beyond the particular social suffering of a single social category. By engaging in a close reading of Kerouac's On the Road in tandem with an autoexperiential account of sociopolitical developments targeting Arab corporeality in the post-9/11 era, this article demonstrates the contradictions and potentialities of social suffering. To be a bearer of an Arab body is to be the on the receiving end of a whole host of societal suspicions, social anxieties, modes of surveillance, military incursions, and, more generally, deployments of negative symbolic power. But this state of domination turned corporeal also makes for a potential site of freedom, a vector for new solidarities with other groups and categories turned alien and other.

What is it to have an Arab body? "When daybreak came we were zooming through New Jersey with the great cloud of Metropolitan New York rising before us in the snowy distance. Dean had a sweater wrapped around his ears to keep warm. He said we were a band of Arabs coming in to blow up New York" (p. 117, Kerouac, On the Road). It's all right there, in Kerouac's novel, everything of relevance has already been said... The Arab's body is violence, an unapologetic celebration of hot-headed exuberance, intemperate and irrational outburst of pure passion: as the Norwegians say, sint som en tyrk, "angry like a Turk." The brown-bodied Orientals, all of the same sort, homogeneous bodies, Deleuze's smooth spaces against the striating maneuvers of Western statecraft...। passed through customs at God knows which one of those miserable US East Coast airports - what was it Joe Biden said? "If I took you blindfolded and took you to LaGuardia Airport in New York, you must think 'I must be in some third-world country'" - you must think - all those brown bodies, crowded and sweating over impossible suitcases, huddled masses, wretched refuse of a teeming shore...

Arriving in America, through the airport, a chaotic mass of automated passport scanners stretched out across the polished airport arrivals hall, how many billions went into them that should have saved the homeless from sleeping under overpasses - self-administered discipline, then, proclaiming the ascendancy of the administered self, even the penalization of the self, no longer a panopticon but a synopticon, even an autosynopticon, a self-seeing-all those automated checkout counters at Safeway must have saved the corporation billions, and when I go grocery shopping, every item bipped is a unit of labor performed for the corporation and its shareholders...At JFK Airport I stood before the machine, scanned my own passport, all those biometric and digital fingerprints sucked up by the machine and fed into the vast surveillance-assemblage, what Lanier (2014) calls "Siren Servers," probably into the Utah Data Center, which mindlessly absorbs "all forms of communication," it has been said, and all this on a beautiful piece of Western land: have you seen the play of light and shadow on ochre hills overlooking these idiotspies in the Utah desert? The cruel machine that guzzles up the earth, when we should all be out hiking under God's sky and find contentment... "Siren Servers are usually gigantic facilities, located in obscure places where they have their own power plants and some special hookup to nature, like a remote river that allows them to cool a fantastic amount of waste heat" (Lanier 2014: xv). But Lanier's technocentricity doesn't allow him to see that all this fantastic data computation is too effective, it captures too much stuff: the siren song of Lanier's Siren Servers is the 
illusion that they actually work; but they can only end in one "giant confusion," as Žižek (2014) says, a confusion that whirls and whorls around the likes of me, and the million innocents, always with the Arab body on its mindless mind...

(Paranoiac moment, another reminiscence: boarding an Air France flight in Paris bound for New York, find myself taken aside at the gate, an additional inspection, but why me? Always this hysterical, insistent self-questioning: why, why me, what have I done? Must've been something I did, the sinking dread that makes guilty men of innocents. Otherwise the Gaze, "lidless and wreathed in flame," wouldn't have thrown its unflinching glare upon your body... which is just where they want you, they've got you cornered now, my boy...And yet isn't the hysteric's discourse the path to liberation? In Gérard Wajcman's (1982/2017) pithy formula: "The hysteric ushers the articulation of knowledge." And we should all be much more hysterical, to break from our somnolent, torpid march through history. (Another reminiscence: a Pakistani friend took his girlfriend from Europe to New York to visit the opera, wealthy types, undoubtedly, he said the whole airport experience left him shaken, he told me this whispering, years later, thousands of miles away, in a dimly lit bar back in Old Europe, still quivering at the memory of humiliation, and his realization of her sudden realization of the insurmountable difference between them, differance all the way down, also, the guilt of being weak, for are we not men? Why should we shudder at uniforms and a few innocent questions? Thin-skinned? Where's your potent masculinity and strength gone? But then again, who can truly stand up against the terrible symbolic might of the state? For the state is "the realization of god on earth," says Bourdieu [2000: 245].) I throw a quick glance at a piece of printed paper left carelessly for all to see on the table where one of the stewards, an apologetic Oriental in Air France uniform stands ready to rifle through our things while all those comfortable passengers sit observing this morality play, something to break the monotony of waiting, Dance Negro! Dance! We're here for their entertainment now, the Theatre of Security ("For theater on a grand scale," says one commentator in the New York Times, "you can't do better than the audience-participation dramas performed at airports, under the direction of the Transportation Security Administration...The T.S.A.'s profession of outrage is nothing but 'security theater'" [Stross 20006] - a profession of outrage, and now l'll profess my own outrage, if I may) - damn you, France, for all your hollow talk of egalité, my soul rages suddenly at this obsequious type, a house Arab working in the master's house. The sheet of paper has my name on it, and six or seven others besides - but by what ghoulish algorithm? With what variables and factors? Checked and crossreferenced by what criteria?)

(And is the Other always consigned to a schizoid discourse? To realize their experiences in linear language must always feel like a betrayal of the authentic experience. The problem of representation is all-consuming, condemned to speak in weird ways and thereby always fail to be properly understood-dismissed and ignored. This skewed meaning is always looked at askance. I have no patience for those well-behaved littérateurs who try to make it at Princeton (Said), in the pages of The Atlantic (Coates) - their thoughts too polite, rarely intruding upon roiling virtuality, which always goes deeper, farther, and is more tangled up than the limitations of social-scientific or analytic-philosophical writing will permit: there's too little of Escher, the Moebius strip, toruses, impossible topological donuts in them.)

Back at JFK: there a cheap little webcam snapped a photo of me, finally the booth spat out a receipt with my name and passport details and picture on it; also, a big, fat " $X$ " across my face, my photograph with an " $X$ " on it, which meant: go talk to a US Immigrations and Customs Enforcement officer, and every time I go to America it's the same, randomly selected for additional screening purposes, etc., and I've stopped going to America now because America makes me paranoid. No clearer expression of the state's discipline than that " $X$ " across your face (I think it was even in red, though I can't say for certain: they made certain they took it away from me when the interrogation, or interview, was over, and can't the absence of an object be as clear an admission of guilt as its presence, negative evidence?)

The Arab body is above all else a paranoiac body. Item: a Welsh (and Muslim) math teacher traveling to the US with a group of schoolchildren: "I gave one of the American officials there my passport. My first name is Mohammed. It felt as if straight away she looked up and said: 'You've been randomly selected for a security check'” (Morris 2017). 
Impersonal bureaucracy becomes intensely personal when confronting the world through the Arab body: the sweat in shoes, the metallic tang of anxious armpits. "I was polite and followed all the instructions. She took me into this room. There were five or six other officials." Sinister secret police officers, security officials, faceless bureacrats, governmental inspectors ready to conduct conduct..."They made me take my jacket off... They made me stand on a stool. They rubbed me all the way down." Inspection as an erotic game, sexual domination, the frisson of the inspector's voyeurism, sadism and glee, imperceptible little shivers of delight from the master's hand - "They even pulled my trousers down to check my boxers..." - inquisitive latex-gloved fingers poking and prodding, probing. "Eventually they let me go through."

Arabicity is not a condition reserved for those ethnoracially or ancestrally hailing from the Arab world but is a condition that spils out from its proper vessel. Anyone can partake of Arabicity, or Arab-ness. Spinoza, the parvenu Sephardic Jew, a wanderer from Iberia to continental Europe, rejectected both by his synagogue as a heretic and by Dutch interiority for his Jewishness, ceaselessly worked on his exterior, his body: "In dress he was conventional and tidy, holding that 'an affectation of negligence is the mark of an inferior mind, in which wisdom is not to be found at all, and in which the sciences can only breed impurity and corruption'" (Scruton 1986: 17). Spinoza's conformity was the product of an "Arab" state of mind: a dominated member of a dominated group, eager to adapt and accommodate himself (but only so that he could work out his madness, his "joyous passion," all the more effectively: conventional on the outside, a genius-madman on the inside). And the paranoia of the Arab is also the paranoia of the not-Arab, mirrored, transposed, and distorted. "I told him a dream I had about a strange Arabian figure that was pursuing me across the desert; that I tried to avoid; that finally overtook me just before I reached the Protective City...Something, someone, some spirit was pursuing all of us across the desert of life and was bound to catch us before we reached heaven. Naturally, now that I look back on it, this is only death: death will overtake us before heaven" (p. 124, Kerouac, On the Road). The Arab as the death-figure, the death-stalker...And what is the opposite of the Other? No antonym for this queer (in all senses) term exists in modern English, only approximately, by its dual meanings: either Self - I am myself, my own self, and you are an other, another-or, a First-I am First, and you are another, an Other (from Old English, oper, "the second, one of the two."). So, two meanings of the Other: the second, and the not-I or not-we. Ordinality and externalization, hierarchy and exteriority, the concept oscillating between the two, forever gyrating, between not-I/not-we and secondariness.

The Arab is a violent body, a risk-filled body, predatorial. "He said he'd seen an Arab in Tunis who could stick a man's eye from forty feet" (pp. 150-151, Kerouac, On the Road). The absence of self-regulation, the id-full (or eidfilled) embrace of Freud's oceanic feeling - total, passionate outbursts of pure bodily lust and the desire to dominate. "For all of Germany, police report that 1,200 women were sexually assaulted and estimate that at least 2,000 men were involved, acting in groups. All of the incidents involved women being surrounded and assaulted by groups of men on the street. Police reported that the perpetrators were men of 'Arab or North African appearance' and said that Germany had never experienced such mass sexual assaults before." We violent predators, we Arab bodies, we sneaky gangs of hoodlums, we debauched wanderers in the night come to feast on your young women - a crazy, spectral force suddenly materialized out of virtuality, all your worst fears embodied and manifested, and on New Year's Eve, come to hail the passing of time itself...These things really happened, of course, let's be absolutely clear on this point, or at least something very much like them, I have no doubt about it, despite the medley of mediatized confusion and political hate-speakers. But-and this is the crux-now all bodies are tarnished, tarred with the same brush, tar and feathers for the young Arab, who is a groper and a rapist, by nature, or by culture, which amounts to the same now, for who can tell where the one ends and the other begins..."She had a diamond ring on her little finger. She leaned on a wall to rest a minute and an Ay-rab rushed up and appropriated her ring finger before she could let out a cry, my dear. She suddenly realized she had no little finger" (p. 151, Kerouac, On the Road). It's all in there, in Kerouac's book, a magnificent, paranoiac prediction from 1957 of our current predicament, which is The Problem of the Arab Body, a clash of civilizations, which means a clash of bodies, prefigured. 
To use our bodies as a canvas on which social history writes itself, to be inspected and interpreted: sociology has yet to learn this hard methodological lesson. To do so not out of reflexive narcissism, but so that one's habitus to can become a "topic and tool" of sociological research, as Loïc Wacquant (2011) says, with the emphasis on the phrase's second half: a tool. Our bodies as tools of the trade, tools of hermeneutic craftsmanship, as sophisticated, if not more, as any Big Data registry or Multiple Correspondence Analysis. We have yet to learn what this fully means: the body as an instrument of science. - Once my beard gets past a certain length, people give me dirty looks on city buses and subway trains in just about every major European metropolis, from St. Petersburg to Stockholm, from London to Berlin. Everyone feels entitled to an opinion about the Arab body, to regulate and circumscribe it, like the bodies of all Others, including women (the makings of an alliance lies here). Old professors at the university joke, "Better shave that beard off before you travel to your next conference, or else they'll think you're IS!" Gleeful, laughs all around, and the dominated can do nothing little more than laugh along with them, save up their bitterness for the lonely hours in the dark... Meanwhile those bearded blondes are "Vikings" or "lumberjacks," manly and legitimate...It must be a wonderful, wondrous thing to have a legitimate body...There are ways to compensate, though - too many to mention, probably. Money and education are the big ones, the timehonored shield of class - "Always insulate!" is the mantra in Tom Wolfe's novel about a social climber - a shield riddled with holes, however...For men, an effeminate demeanor, to be gentle, to carry one's body softly, with no sudden movements, smooth rather than jerky motion, as if to say, "I'm harmless, here's no danger, move along, Gaze."

Hypercorrection, Bourdieu calls it (a term borrowed from linguistics), "very common in first-generation immigrants undergoing integration and eager for recognition" (Bourdieu 2004: 13). Abdelmalek Sayad says that dominated populations always "experience the body as the geometric locus" of domination: the body is worked upon by society, and they in turn must work upon their bodies; they are forever polishing themselves, scrubbing at all negative inscriptions (Sayad 2004: 260). While the dominant can afford to indulge in hypocorrection (speaking downwards, acting beneath their station), the dominated have no other option save hypercorrectness: the wellgroomed immigrant man on his way to work in the morning, looking trim and dapper - but doesn't he know that his perfectly styled hair and freshly bought shoes declare him for what he is, a member of the dominated fractions, a spectacle of power deployed, and for all to behold? It's an obscenity to play their game! Like masturbating in public? And yet what choice does he have but to ejaculate his immaculate manners? Put them at ease, it makes living so much easier, comfortable, and we all want to be comfortable...(Jack Lemmon once said that in order to play a drunk, you must never slur, but always speak with enormously precise diction - the idea being that enunciating each word in an exaggeratedly clear fashion dupes the audience into thinking the actor really is covering up a state of intoxication - and far more convincingly than any artificial slurring would. Hypercorrection as a source of authenticity, then. The inverse is true for our case, perhaps. Our advice to all Others should be: permit yourself to slur and slouch! The true mark of nobility! Falsify your absent aristocracy! Though the hounds would probably soon be on their trail, then as now...the infinite regress, all those endless double binds. The tragedy of domination is, also, that it can never be fully repressed. It will always return - often at the most inopportune of times.)

One of Kerouac's favorite words was fellahin (which he usually spelled fellaheen, and probably took from Spengler). A fellah, "an Egyptian peasant," from Arabic, "fallāh 'tiller of the soil.'” The fellah is rooted to the earth, and therefore, though fixed more closely to the ground than climbers and the cultured, still sees more, and sees more truly: "But you can find it, this feeling, this fellaheen feeling about life, that timeless gayety of people not involved in great cultural and civilization issues" (Lonesome Traveler). And while the word's origins are Arabic, Kerouac used it often enough in describing Mexican peasants and laborers to suspend the term's cultural particularities. Here's a clue about the contradictory representations of the Arab body: the fellah, the peasant, the soil-tiller, but, both more particularly and more broadly, the Arab body, comes to stand, strangely enough, for the universal subject - which is the Marxist proletarian as a universal class, translated into culturalist terms. This almost magical word, an incantation, contains the dialectical lesson of the particular-universal binary taken to its radical endpoint: that true particularity only arises out of the universal, and the truly universal only comes from particularity. This elevation of 
the fellah-subject to a position of transcendent universal is always unstable. It has always seemed particularly prone to destabilization. Seinfeld's irrational, hateful "Soup Nazi” (Seinfeld, Season 7, Episode 6) with his vaguely Saddamite mustachio, foreign accent, swarthy looks, violent intolerance: the very epitome of a negatively charged Arab body, as represented in popular American culture. The French documentary series Apocalypse: Staline (2016) briefly intimates that the dictator's vicious machinations can be explained by his Georgian origins, his hot "Southern" temperament, "Asiatic" despotism...Or the Jack Ryan film, The Sum of All Fears (2002): an Arab desert-wanderer sells a nuclear bomb to a South African arms dealer for a pittance, and is content with it, because the arms dealer appeals to this Arab's "idiotically" pre-modern honor code, by "paying for the death of your son" (in the film, his son was killed in an Israeli airstrike in 1973), a modern twist on that old myth of the purchase of Manhattan for a handful of glass beads... Recall Jack Shaheen's analysis of Hollywood's representation of the Arab body: out of 1,000 films between 1896 and 2000, more than 900 were negative (Shaheen 2003). Fanon's colonization of the psyche begins at the box office. There runs a straight line-not a line of flight-from the movie theater to mental hospital. With "successful colonization," the "defensive attitudes of the natives give way" and they find themselves grappling with "mental pathology," Fanon wrote (1963: 250-251). And the Arab body has been most successfully colonized.

Orientalism abounds, or rather (for isn't Orientalism the wrong term: isn't the Orient almost always eastern Asia, not the "Near East"?), the Arab body is everywhere once you start looking, and it is forever biting its own tail, lopping off its own head, regrowing new heads and tails...It is much crazier than Said could ever appreciate-Said was too polite, too much of a Princetonian, with his French literature and piano, eager to play the Ivy League game, he was too much of a child of the élites - all of them, nearly (in a memoir of her father, Said's daughter complains that they lived on the Upper West Side, and not the Upper East Side, and so she felt alienated at the private school her father sent her to [see Said 2013], but doesn't realize that what this quandary over [Upper] East and [Upper] West betrays is the near-total privilege of lives led among distinguished elites-and strangely ironic, too, of course that this expert of the Orient had to "make do" with the West, couldn't afford the East). He did not have much patience - not enough, anyway - for the grit and dirt of his chosen subject: Said's (1979) Orientalism was a "methodology of the text," as Turner notes (1994: 4), not a methodology of the body. A disembodied account, in fact, conspicuously lacking in corporeality. Where was his own body amid all those musty texts of centuries gone? Why hide it? But Turner's (2004) critique of Said's Orientalism falls flat on its face: “It would not be possible to develop something called Islamic social science, for the same reason that you cannot have Christian social science or Jewish social science or any other type of ethnic social science" (Turner 2004: 8). Isn't this merely the orthodox sociological erasure of whiteness as the (Husserlian) habitual "orientation" to the world, in Ahmed's (2007) terms? Whiteness is "“the behind"” that "'goes unnoticed,"” Ahmed (2007: 156) writes, "a background to experience" that is naturalized and consequently forgotten. The proper response to Turner's dismissal of "ethnic social science" is to point out that traditional social science has always already been ethnicized: conventional social science is (disavowed) white social science.

(We can trace such naturalizing maneuvers in popular culture, too. In the mid-1980s, the French singer Daniel Balavoine produced a a hymn against racism, as it has been called, with the hit single "L'Aziza." The song was replete with Orientalisms, a declaration of love for one Aziza, a woman from an unnamed North African country: "Ta couleur et tes mots tout me va" ("Your color and your words are all the same to me"), i.e. her brown skin and barbaric words - recall that ßápßapoc derives from the ancient Greeks' uncomprehending attitude, the babbling "bar bar" of their Anatolian neighbors-don't bother Balavoine's character, he tolerates them both, which is perhaps the clearest expression of why the tolerance-intolerance axis mobilizes the wrong categories of critique, as Žižek (2008) has noted. Seemingly, it never even entered Balavoine's (or his character's) mind that his own color -or its putative absence-and particular language could be the subject of a reciprocal questioning and mutual doubt...The erasure of whiteness, those brown bodies always imposing themselves... To be legitimate is to be above questioning.) 
The Arab body, then, as huckster, trickster, violator, but also the at-peace figure, the harmonious, contented man, living off the fat of the land, a brown-earth soil-wanderer. "Ten miles down the road Dean drove into a filling-station with the motor off, noticed that the attendant was fast asleep at the desk, jumped out, quietly filled the gas tank, saw to it the bell didn't ring, and rolled off like an Arab with a five-dollar tankful of gas for our pilgrimage" (p. 139, Kerouac, On the Road). Cunning thievery, the contented little thief, pilfering honest American gasoline from honest, sleeping American gas station attendants, naïve, somewhere in America, the Arab versus America, which is just the struggle between dark and light...But again, things aren't so simple or straightforward. The Arab is also release, transcendence, a moving-beyond-self, which is the unattainable dream-state or frenzy-state that all humanity should aspire to. And so, again, this strange duality: the risk, the hatred, the fear, the danger, the loathing - but also the ideal, the object of desire, the thing to be emulated. Revulsion intermingled with jealous desire. And so, "in this welter of madness I had an opportunity to see what Dean was up to. He was so out of his mind he didn't know who I was when I peered at his face. 'Yeah, yeah!' is all he said. It seemed it would never end. It was like a long, spectral Arabian dream in the afternoon in another life-Ali Baba and the alleys and the courtesans" (pp. 290-291, Kerouac, On the Road). The serenity of the Arab's body, the dream-like fugue state and ecstasy of Arabicity, "and then Slim goes mad and grabs the bongos and plays tremendous rapid Cubana beats and yells crazy things in Spanish, in Arabic, in Peruvian dialect, in Egyptian, in every language he knows, and he knows innumerable languages" (p. 178, Kerouac, On the Road). In short, the Arab body: one long, unceasing problem - for them, but also for us.

\section{References}

Ahmed, Sara (2007). "A phenomenology of whiteness." Feminist Theory 8(2): 149-168.

Bourdieu, Pierre (2000). Pascalian Meditations. Stanford: Stanford University Press.

Bourdieu, Pierre (2004). Science of Science and Reflexivity. Chicago: The University of Chicago Press.

Fanon, Frantz (1963). The Wretched of the Earth. New York: Grove Press.

Lanier, Jaron (2014). Who Owns the Future? London: Penguin.

Morris, Steven (2017). "British Muslim teacher taken off US-bound flight: I was treated like a criminal." TheGuardian.com, 21 February 2017. https://www.theguardian.com/us-news/2017/feb/21/british-muslim-teachertaken-off-us-bound-flight-i-was-treated-like-a-criminal.

Said, Edward W. (1979). Orientalism. New York: Vintage Books.

Said, Najla (2013). "My father, Edward Said." Salon.com, 8 April 2013.

https://www.salon.com/2013/08/04/my_father_edward_said/.

Sayad, Abdelmalek (2004). The Suffering of the Immigrant. Cambridge: Polity Press.

Scruton, Roger (1986). Spinoza. Oxford: Oxford University Press.

Shaheen, Jack (2009). "Reel Bad Arabs: How Hollywood Vilifies a People." The Annals of the American Academy of Political and Social Science, 588 (July): 171-193.

Stross, Randall (2006). "Theater of the Absurd at the T.S.A." NYTimes.com, 17 December 2006. http://query.nytimes.com/gst/fullpage.html?res=980CE1D91231F934A25751C1A9609C8B63\&pagewanted=all.

Turner, Bryan S. (2004). Orientalism, Postmodernism and Globalism. London: Routledge.

Wacquant, Loïc (2011). "Habitus as topic and tool: Reflections on becoming a prizefighter." Qualitative Research in Psychology 8(1): 81-92. 
Wajcman, Gérard (1982/2017). “The Hysteric's Discourse.” http://www.lacan.com/hysteric.htm.

Žižek, Slavoj (2008). “Tolerance as an Ideological Category.” Critical Inquiry 34, no. 4 (Summer 2008): 660-682.

Žižek, Slavoj (2014). “Slavoj Žižek + Paul Holdengräber, 'Surveillance and whistleblowers'” [video]. Det Kongelige Bibliotek, Copenhagen, Denmark. 19 May 2014. https://www.youtube.com/watch?v=PIPjmmmh_os.

\section{Cite this Essay}

https://doi.org/10.20415/rhiz/034.e09

RHIZOMES ISSN 1555-9998 $\star 230$ East Hall Bowling Green State University Bowling Green, OH 43403

Editors: Ellen Berry and Carol Siegel. Reviews editor: Craig J. Saper. Technical editor: Helen J Burgess 